\title{
GRG Profiles: George Triadafilopoulos
}

\author{
George Triadafilopoulos ${ }^{1}$
}

Published online: 13 February 2016

(c) Springer Science+Business Media New York 2016

\section{Zero to Sixty... in No Time}

Sometimes, particularly when we are waiting for something, time stays at a standstill. But mostly, particularly with memories, time gallops forward amazingly fast. So, when I was asked to write my story in these pages, the speedometer of life came to mind and I realized how quickly everything went. Hence "zero to sixty" and the breakdown in decades.

\section{Zero to Ten}

I left my mother's silent and salty aquarium on a hot afternoon in August 1955. My cries and first few breaths made me aware of my new irreversible existence that joined many others in the small city of Patras, Greece, at the Northwestern part of the Peloponnese. Thousands of years ago, that land and its surrounding blue waters were ravaged by decades of war. But on this day, everything was serene and welcoming. Somehow I remember the sun penetrating and giving the nursery a unique whiteness and brightening my mother's smile. My parents had fought and survived the recent deadly war in Europe. I was elected as their hope for a better life, a future that did not seem possible some years earlier. My beginning was joyfully wrapped in the unknown of responsibility and expectations: the so-called post-war generation that would bring goodness to the world, a new way of life, kind, and caring.

George Triadafilopoulos

vagt@stanford.edu

1 Division of Gastroenterology and Hepatology, Esophagus Center, Stanford Health Care, 900 Blake Wilbur Drive, Palo Alto, CA 94304, USA
Years later I happened to read the New York Times issue of that special day of my birth. Tuesday, August 30 was a pleasant day in New York, sunny and $75^{\circ}$. President Eisenhower was negotiating with the Soviets, Israeli and Egyptian jets who were clashing over Gaza, and the Brooklyn Dodgers had defeated the Cardinals 10-4. Madison Avenue was filling the pages with black and white drawings of women in elegant dresses, cars, and household gadgets, and the New York Central Railroad was promising to revolutionize travel, increase employment, and strengthen the US national defense. As I was taking the shape of a boy about to change the world, life around me was not ready to give in. Sixty years later, "all the news that's fit to print" was not that different (although the Dodgers are no longer in Brooklyn). The fantastic promise of my existence and that of others of my generation had created a faster, uncertain, and chaotic universe.

I think I am writing the truth about my first 10 years, but I am not sure that such truth was not the product of my imagination. Growing up during those years without telephone, television, and other media of communication was so peaceful, almost dreamy. The radiance of the sun, the cloudless skies, and the occasional full moon were defining my otherwise limited world borders. As an only child, I was at the center of attention, blessed by my family's devotion, caresses, and collective wisdom. My new everywhere was anything in print: books, children's comics, magazines, illustrated glossy English and French, Greek, or Italian, for children or adults. Books, then and now, never betrayed me, and reading quickly became my escape and my salvation. Their smell and texture, their markings made by previous readers in our family, even the dust on their covers, the hand-written side notes dated from years past assured me that I would conquer all my childhood fears. Becoming aristos was my path, based on my inclination and ability, if fate would allow. 


\section{Ten to Twenty}

Short khaki pants, a bike, and polo shirt defined my first several teenage years, surrounded by my buddies, their anxieties and mine, and my early explorations of the better sex. Unsuccessful in and disinclined to sports, I would observe my slow but steady growth toward becoming a generally introverted adult, with sparse individual but highly rewarding friendships enriching my social world and status. The family home, its long staircase, high ceilings, and dark walls decorated with nineteenth-century paintings and studded by Viennese-style furniture, assured me of a long tradition of sophisticated life that I was expected to live and flourish within. I had to draw and pursue my own trajectory commensurate with hundreds of years of tradition in my family and our culture. Boy Scouts and visits to the church did not help. Illness and the medicine cabinet came to my rescue.

Midway through the torments of teenage, I was exposed to the power of healing. Our family physician, his stethoscope in hand and his pills and injections in a magic black bag, would visit regularly my sick mother, who was writhing in pain and consumed by fever. Recognizing human vulnerability prima facie and admiring the success of modern Medicine 1 week later had an irrevocable impact on a young boy. Suddenly, I had a purpose, a plan, and a destination. Suddenly clarity, commitment, and fearless determination were to be externally matched by my long jeans, long hair, and green military jackets. The newly acquired TV set at my aunt's house would host my dreams through Dr. James Kildare and Marcus Welby, MD. One day, my star would shine, or so I thought.

I remember those summers when Rimbaud, Proust, and Montaigne were put aside and replaced by my sentimental education through sea, sex, and sun, hiding my anxieties under a mask of coolness. Sartre, Barthes, and Camus were read together with her or them, discussed, and re-examined by a bonfire, under the influence of alcohol and tobacco. I was smitten by the nighttime swims in the Ionian Sea, the sweet touch of the other body, their salty taste, their scent, and their incomprehensible effect that had the power to destroy our sensitive souls. Then came medical school at 18 , the other (more adult) parties, and the wisdom of many emotional defeats. The library around me changed; its books became dry and dogmatic, and there came the smell of the cadavers and test tubes, the cells, the rats and, soon thereafter, I was faced with my first real patients.

\section{Twenty to Thirty}

Every one of my clinical rotations during medical school was poised to make me the next best clinician of that discipline. The exuberance of the unknown to be explored, the vastness of biology and illness, the allure of becoming someone useful to others, and the relentless exposure to human suffering were contagious, seductive, and often overpowering. Beyond the Greek borders, I explored how medicine was practiced in Europe, taking rotations in England and France, testing the prospect of a post-graduate education. At the tender age of 24, diploma at hand, I was ready to conquer the world of medicine with a Don Quixote attitude and confidence.

Detroit circa 1980 did not exactly represent the "grand" America that a European youth had constructed in his mind from books and magazines. Yet, the boarded houses, abandoned cars, and devastation of crime, and poverty that surrounded the hospital buildings at the downtown medical center annihilated the intimidation of a young foreigner. The ensuing endless days and nights as a house officer in Internal Medicine were demanding, disciplined, mostly invigorating, but occasionally exhausting. To alleviate the pains of growing up as a young doctor in training came the delights of two children, our son on a balmy June afternoon, and our daughter 1 year later, on a freezing December evening. At 27, the citizen, husband, doctor, parent could deal with anything, simple or extreme.

Boston not only welcomed our young family, but also funneled our confidence, intellect, and excitement for learning into a unique blend of highly gratifying professional and social pursuits. Training in gastroenterology under Tom LaMont was a balancing act of clinical relevance, the research question, and deep understanding of gut physiology. Endoscopy was young in those days, but we explored every one of its aspects tirelessly. Every day was a symphony of test tubes, patients, drawing boards, endoscopy, cells, and animal experiments. Every evening was a gathering of friends talking about world politics, music, and the arts, thinking of the future and shaping it.

\section{Thirty to Forty}

Northern California welcomed us with a near perfect climate, a nice suburban house by the golf course, and a wellcompensated leadership position. At 33, I was in charge of a GI division and a fellowship program, as well as an endoscopy unit and research laboratory. Almost unreal by today's standards, this responsibility fueled a frantic productivity, clinical and experimental, and a clinical and educational expansion that included five hospitals in the San Francisco Bay area. Boston's upbringing was given the chance to prove its worth, and it did.

It is hard to believe that the tectonic shifts of the Bay could have an impact on someone' s career, but the restructuring of the VA hospitals after the Loma Prieta earthquake brought us to the Palo Alto VA and Stanford, joining a budding team of clinicians and investigators 
under the leadership of Harry Greenberg. Starting out in temporary buildings and eventually in a state-of-the-art hospital, my colleagues and I not only took care of a large number of patients, but also initiated a large network of basic, clinical, and translational research on colon polyps, screening colonoscopy, gastroesophageal reflux disease, and Barrett's esophagus and cancer, among others. Triggered by clinical questions at the bedside, we would create laboratory experiments, and then, guided by their results, we were able to conduct clinical trials that within years would change clinical practice. Blessed by Stanford's open-minded research and entrepreneurial community, we also explored new technologies and concepts, some with quick clinical implementation, others less gratifying. More importantly, the Palo Alto VA became a forum for clinical and research training to many young US and foreign gastroenterologists who, after spending some time with us, moved on and currently represent the world's key opinion leaders.

\section{Forty to Fifty}

One of the perks of academic life and its successful research activities is travel. Back then, a lot of such travel was to attend meetings put together by the drug and device industry, but some was on behalf of universities and large hospital chains as well as professional groups. Travel can be intellectually invigorating, both from the perspective of interacting with colleagues and, at times, competitors, but also because it allows you to visit other parts of the world where different standards and attitudes apply. Upon return, you are enriched with ideas and impressions, some applicable and some not, but with an ever-increasing global perspective.

It was with this global perspective that I transformed Gastrointestinal Endoscopy (GIE), aiming to make it the premier endoscopy journal in the world. For this, I surrounded myself with an international group of endoscopic clinician-scientists who shared this common goal. Over the next 5 years, we were blessed with unprecedented levels of readership, popularity, and scholarly recognition. Again, I was the beneficiary of a great team effort by my group of editors, who, like my colleagues back in Palo Alto, were outperforming themselves. The chief editor's job, much like that of an orchestra conductor, requires a unique mix of skills, from business to medicine, and a strong but affectionate personality.
For several reasons beyond my control, I also made another dramatic professional move. I left the VA and opened my own private practice in nearby Mountain View. I had become increasingly unhappy about the control of our practice by number crunchers who had infiltrated our ranks and were controlling our clinical and research activities. I was convinced that I could still effectively do what I really cared the most about — patient care — and combine this with a continuous effort in clinical research and fellows' education. Although I maintained a teaching role at Stanford, I was able to make my own time for whatever I wanted to do in the clinical and research domains. It was a liberating experience that I cherish and recommend to this day.

\section{Fifty to Sixty}

During my early fifties I would say that I was riding on a fast wild horse, enjoying a successful professional practice, intellectual scientific pursuits, and a rich and highly fulfilling personal life. With time under my control, I was able to choose to practice medicine 1 day or sail on the Bay another. Everyone, but particularly those of us who have worked very hard during our growing days, deserves such a golden period in his or her life. In my case, the intensity and variety of that period were enough for a lifetime, but it came to an abrupt end.

I was on a riverboat cruising the Mekong River when I was struck by the lightning of a spinal cord hemorrhagic infarct that has since left me paraplegic. In a matter of seconds, the life I knew was irreversibly gone. It was a grave event that almost took my life and guaranteed my dependence on others forever. It was also an event that angered me, depressed me, made me volatile and vulnerable, more human, and much less of a god. Three months later, tired of passivity, I confronted my left-handed fate and went back to work. I was lucky that I could see and examine patients, perform endoscopy, and be just a halfmoving part of my old self. And I was lucky that I was with my partner who not only loved me, but cared deeply about my predicament and tirelessly looked after me.

We celebrated my 60th birthday overlooking the Mediterranean Sea in Monte Carlo. I was there presiding over an international esophagus meeting and actively participating in lectures, debates, and discussions. My partner and I looked at each other's eyes reflecting the shiny blue waters, and we exchanged a new set of vows: to prevail against any harsh reality, present and future. We are young and strong, we both said, and we both believed it.... 